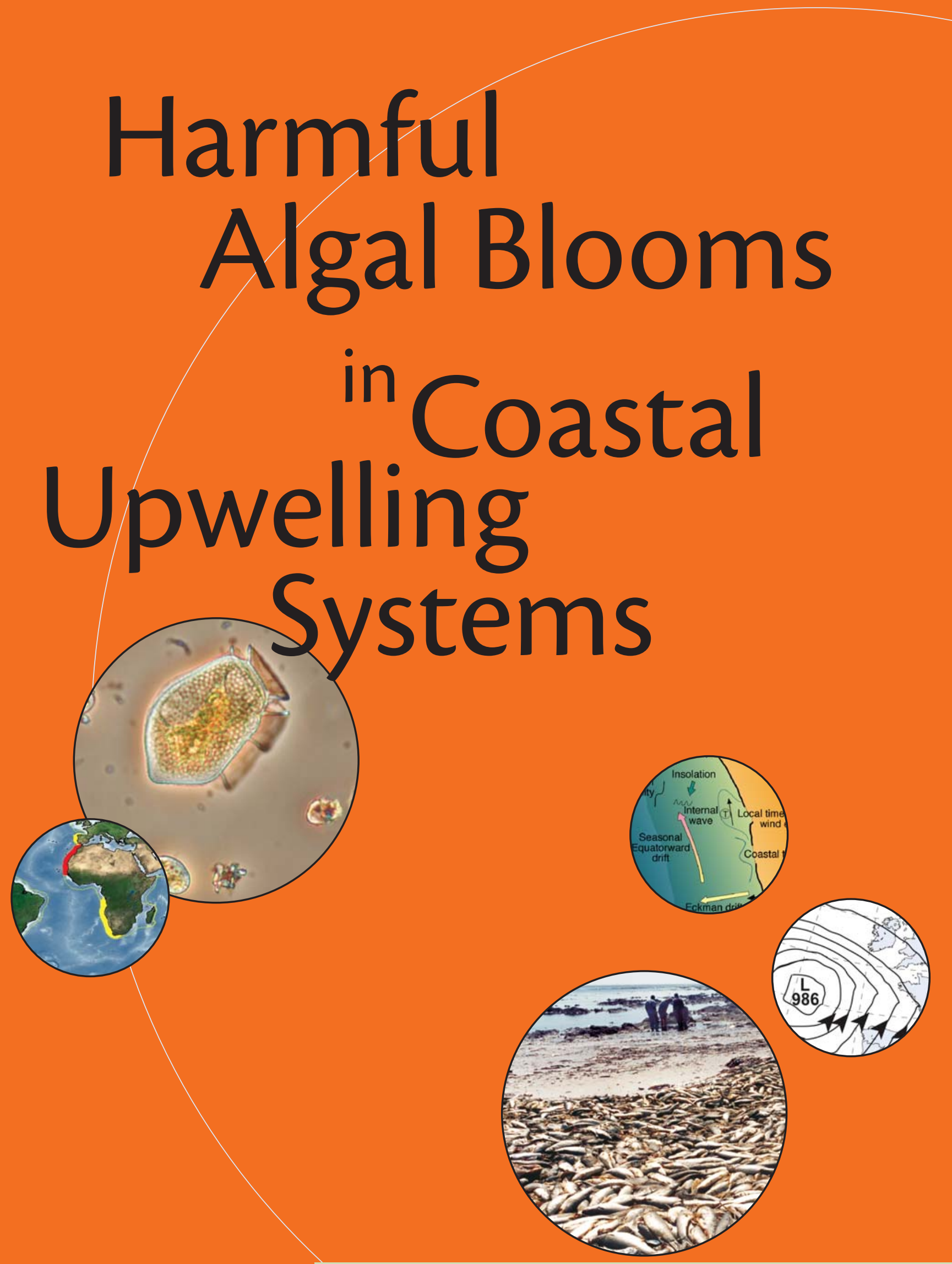



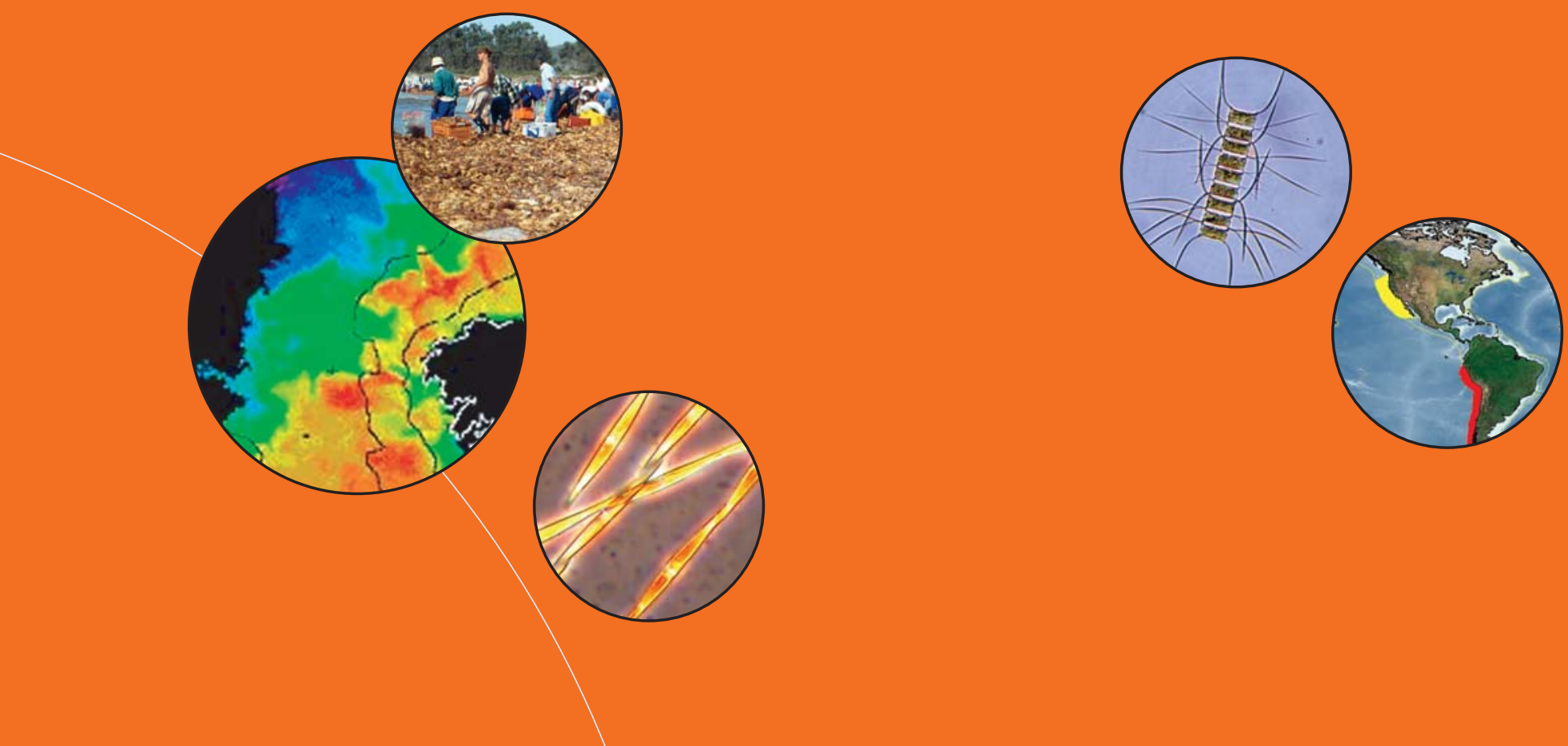

BY RAPHAEL KUDELA, GRANT PITCHER, TREVOR PROBYN, FRANCISCO FIGUEIRAS, TERESA MOITA, AND VERA TRAINER

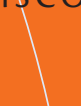

he California Current, Humboldt Current, Canary Current, Iberian Coastal System, and

Benguela Current represent five Large Marine Ecosystems (LMEs) associated with eastern boundary upwelling regimes (Figure 1). LMEs are characterized by distinct bathymetry, hydrography, productivity, and trophically dependent populations. Most of the global ocean pollution, overexploitation, and coastal habitat alteration occurs within LME waters. The highly productive upwelling regimes account for a large fraction of global fisheries production (Figure 2), but similar to all other marine environments, are increasingly susceptible to the proliferation and negative effects of harmful algae (Figure 3). These impacts include human and marine organism illness and death due to direct toxic effects, environmental degradation due to, for example, increased biological oxygen demand, declining fisheries and growth of coastal communities, "nuisance" effects such as discoloration of the water, and more subtle changes to the ecology of these marine systems.

A GEOHAB Open Science Meeting held in Lisbon, Portugal in November 2003 (GEO$\mathrm{HAB}, 2005$ ) targeted the California, Iberia and Benguela Current upwelling systems (Figure 4). Here we provide an overview of harmful algal blooms (HABs) in these upwelling systems, and present the key questions to be addressed in understanding the ecology and oceanography of HABs in these eastern boundary systems. 
THE PHYSICAL SETTING

\section{AND SUCCESSION OF}

\section{PHYTOPLANKTON}

Unlike many other ecosystems impacted by harmful algae, upwelling systems worldwide are dominated by a common set of physical parameters and are likely to respond similarly, regardless of locale. Winds blow alongshore towards the equator for at least some part of the year and Ekman transport in the surface boundary layer is directed offshore. The existence of the coastal boundary imposes a divergence in the surface layer, resulting in upwelling of cold, nutrient-rich waters near the coast. The measured cross-shelf transport in the surface boundary layer is in quantitative agreement with that predicted from wind stress. The boundary along the coast between the upwelled water and the warmer adjacent ocean surface water is usually a front with an associated equator-ward jet (Smith, 1992). The biological counterpart to the surface boundary layer is, roughly speaking, the euphotic zone into which nutrients upwell, leading to high productivity. Consequently, upwelling circulation overrides both the nutrient limitation of stratified waters and the light limitation of well-mixed waters (Hood et al., 1992).

HABs in upwelling systems have

Raphael Kudela (kudela@ucsc.edu) is Assistant Professor, Ocean Sciences Department, University of California, Santa Cruz, CA, USA. Grant Pitcher is Principal Specialist Scientist, Marine and Coastal Management, Cape Town, South Africa. Trevor Probyn is Senior Specialist Scientist, Marine and Coastal Management, Cape Town, South Africa. Francisco Figueiras is Professor, Instituto de Investigaciones Marinas-CSIC, Vigo, Spain. Teresa Moita is Professor, Instituto Nacional Investigacao Agraria Pescas, Lisbon, Portugal. Vera Trainer is Research Oceanographer and Program Manager of the Harmful Algal Blooms Research Group, Northwest Fisheries Science Center, NOAA, Seattle, WA, USA.

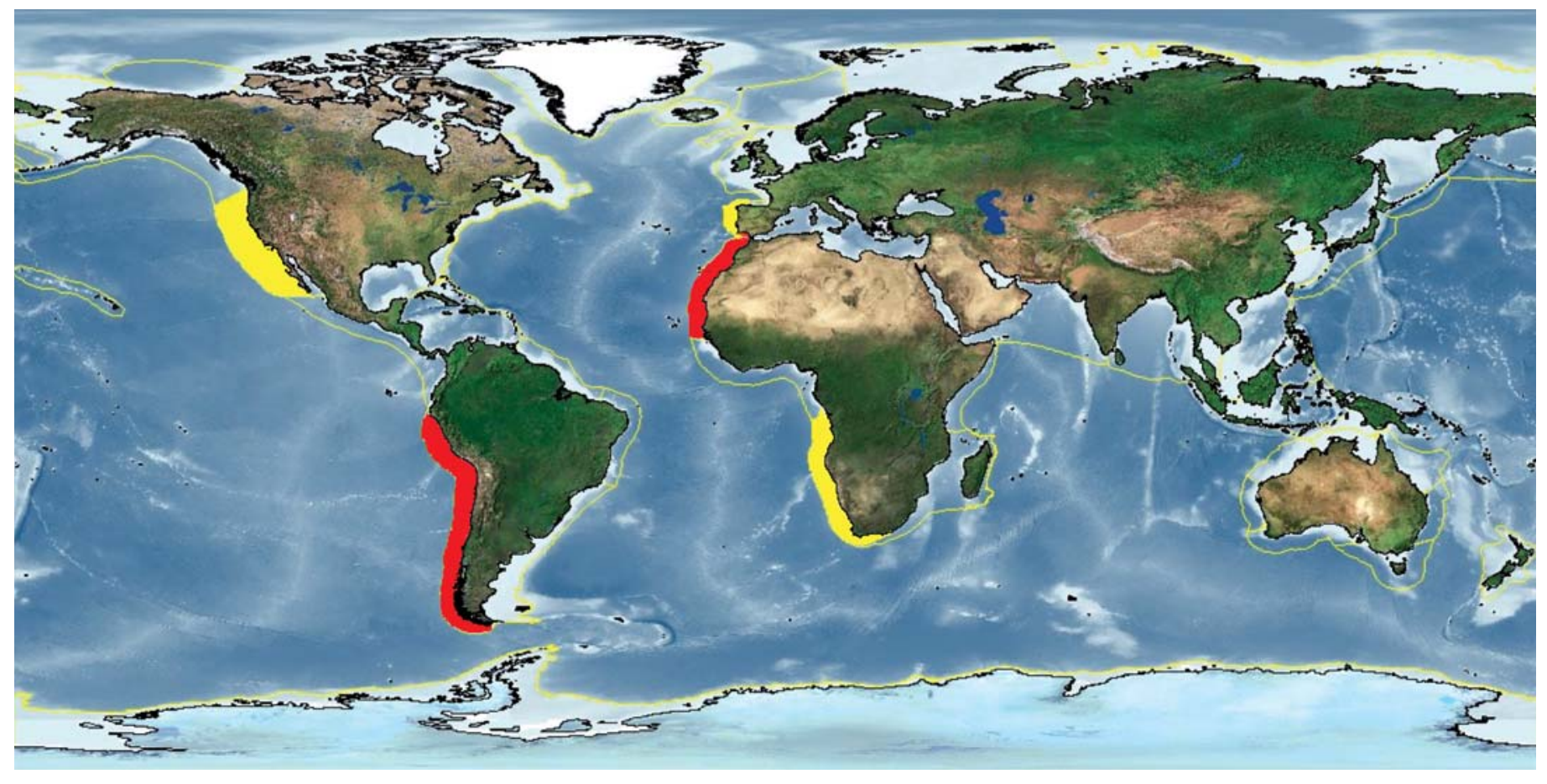

Figure 1. Large marine ecosystems (LME) of the world (Sherman and Alexander, 1986). The three eastern boundary current regimes that we focus on (the California, Iberian, and Benguela Current systems) are highlighted in yellow, while the remaining two large eastern boundary current LMEs (the Humboldt and Canary Current systems) are highlighted in red. The other global LME boundaries are delineated with yellow lines. Original image courtesy of NOAA (http://www.Ime.noaa.gov). 
been closely linked to wind, which is the main driving force in upwelling systems (Pitcher et al., 1998). HABs therefore vary considerably at a variety of temporal scales related to atmospheric oscillations (Figure 5). Annually, HAB variability results from the displacement of atmospheric high-low pressures dipoles, which influence alongshore winds, favoring either upwelling or downwelling (Figure 6). Transition periods occur in spring and autumn. However, variations in the wind regime due to changes in the position and/or strength of the highlow pressure systems cause short-term variability in upwelling-downwelling cycles within each season (Hickey, 1998).
Water-column responses to these upwelling-downwelling cycles during the upwelling season are modulated by the
Interannual fluctuations related to the El Niño-Southern Oscillation (ENSO) and longer-term cycles, such as the $\mathrm{Pa}-$

\section{The highly productive upwelling regimes account for a large fraction of global fisheries production, but similar to all other marine environments, are increasingly susceptible to the proliferation and negative effects of harmful algae.}

degree of thermal stratification, which at temperate latitudes evolves from the weakest stratification in spring to the strongest in late summer-early autumn. cific Decadal Oscillation (PDO) and the North Atlantic Oscillation (NAO), also affect these coastal upwelling systems through modifications of seasonal up-

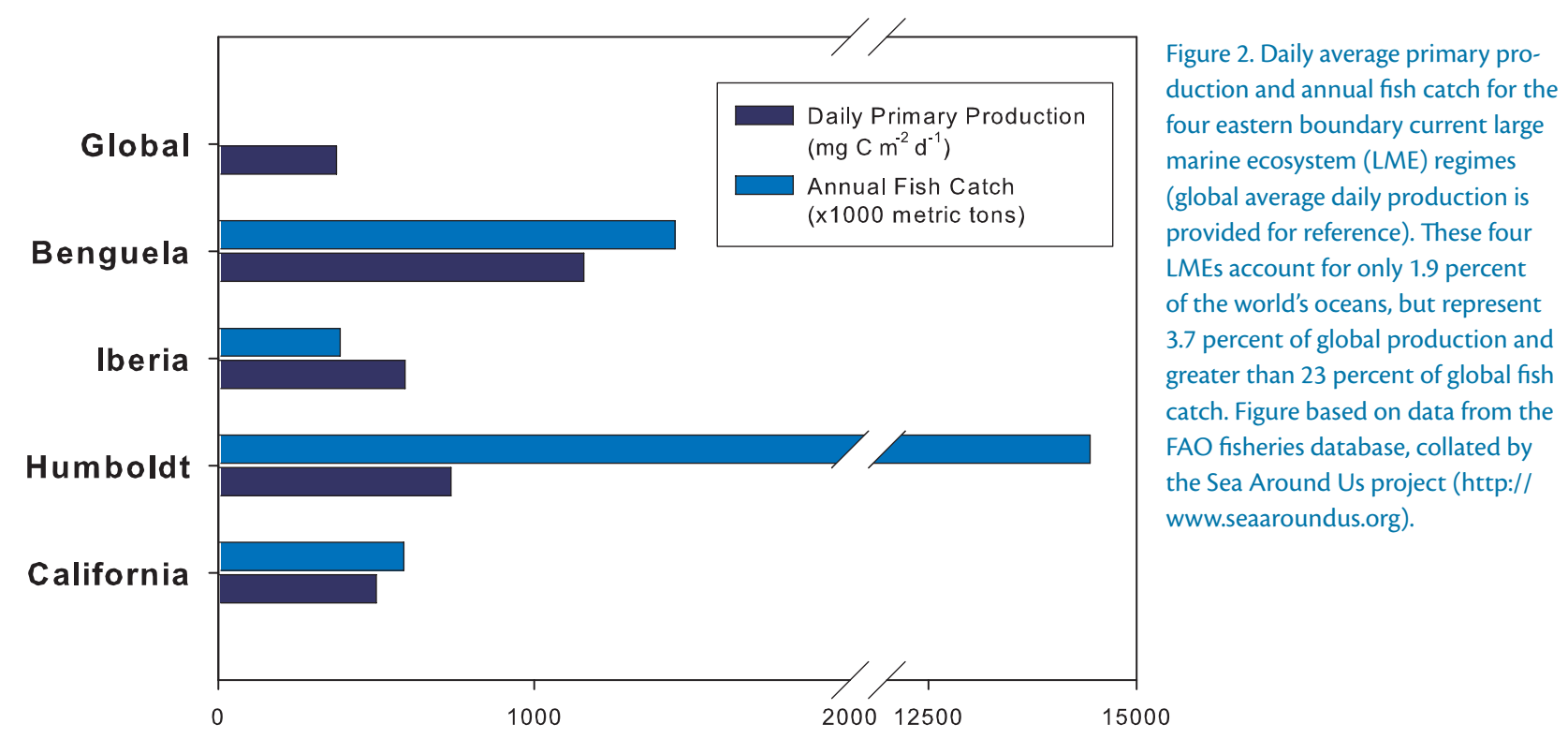



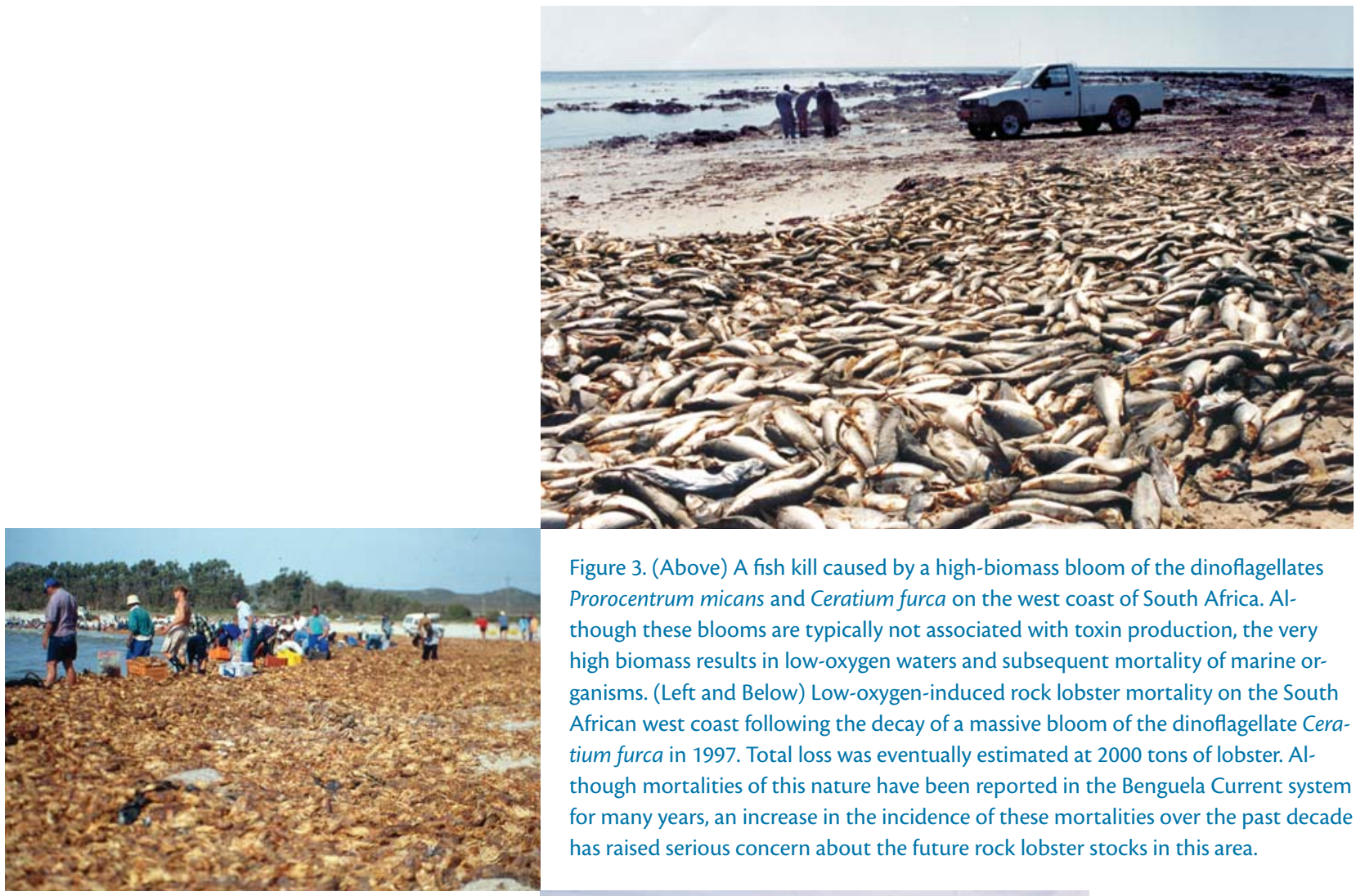

Figure 3. (Above) A fish kill caused by a high-biomass bloom of the dinoflagellates Prorocentrum micans and Ceratium furca on the west coast of South Africa. Although these blooms are typically not associated with toxin production, the very high biomass results in low-oxygen waters and subsequent mortality of marine organisms. (Left and Below) Low-oxygen-induced rock lobster mortality on the South African west coast following the decay of a massive bloom of the dinoflagellate Ceratium furca in 1997. Total loss was eventually estimated at 2000 tons of lobster. Al-

though mortalities of this nature have been reported in the Benguela Current system for many years, an increase in the incidence of these mortalities over the past decade has raised serious concern about the future rock lobster stocks in this area.

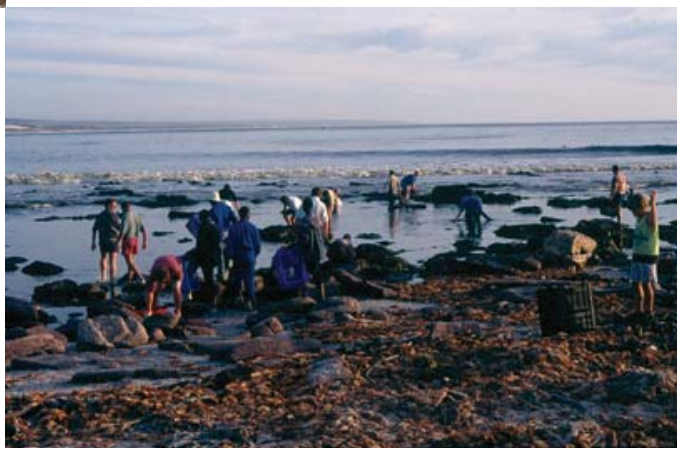

welling-downwelling strength (Shannon et al., 1986; Alvarez-Salgado et al., 2003; Chavez et al., 2003).

Within this general context, physical features along the coastline, such as capes and embayments; particular topographic features of the slope and continental shelf such as canyons; and steep variations in the isobaths, the presence of buoyant freshwater plumes, and the dynamics of oceanic margins, generate instabilities in the flow that alter this general circulation pattern at several spatial scales. In general, topography and coastline orientation interact with wind forcing by modifying the along-shore and cross-shelf flows at different levels, resulting in amplification and/or reduction of upwelling-downwelling. Coastal buoyant plumes arising from continental runoff can prevent the surface expression of upwelling or prevent onshore transport during downwelling.

The main patterns of phytoplank- 
ton biomass in upwelling systems are related to water-column stratification, nutrient availability, and the intensity and persistence of upwelling conditions. Maximum values of chlorophyll usually occur in spring and summer for the Iberian and California systems, and in the (austral) summer and autumn for the Benguela Current, although high chlorophyll values may also be recorded at other times of year, particularly in zones with elevated retention characteristics. Nearshore waters of the Benguela Current have been classified based on their sequential development following upwelling (Barlow, 1982). Type 1 water corresponds to newly upwelled water with a temperature of less than 10 degrees $\mathrm{C}$, a chlorophyll $a$ concentration of less than $1 \mathrm{mg} / \mathrm{m}^{3}$, and high concentrations of inorganic nutrients. Type 2 water corresponds to maturing upwelled water and is characterized by temperatures greater than 10 degrees C, chlorophyll $a$ concentrations of 1 to $20 \mathrm{mg} / \mathrm{m}^{3}$, and nitrate $a$ concentrations that typically range between 5 and $30 \mathrm{mg} / \mathrm{m}^{3}$. Although developed specifically for the Benguela Cur-

These impacts include human and marine organism

illness and death due to direct toxic effects, environmental degradation due to, for example,

increased biological oxygen demand, declining

fisheries and growth of coastal communities, "nuisance" effects such as discoloration of the water, and more subtle changes to the ecology of these marine systems.

concentrations of 2 to $15 \mathrm{mmol} / \mathrm{m}^{3}$. Type 3 water of between 12 and 16 degrees $\mathrm{C}$ corresponds to aged upwelled water and contains low concentrations of nitrate of less than $2 \mathrm{mmol} / \mathrm{m}^{3}$ and chlorophyll rent system, this classification scheme is readily translated to the other eastern boundary current systems.

The seasonal succession of microplankton in upwelling systems follows

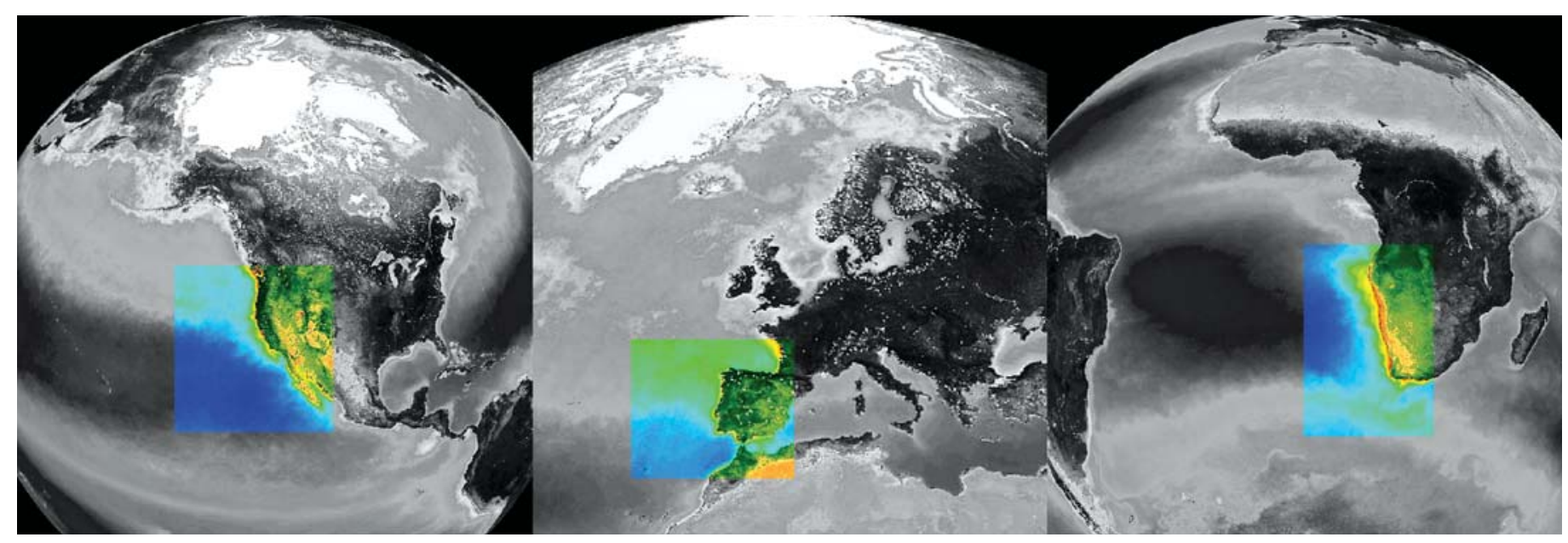

Figure 4. The three major eastern boundary current large marine ecosystems considered as part of the GEOHAB Open Science Meeting on HABs in Upwelling Systems. Left: the California Current System. Middle: the Iberian Peninsula. Right: The Benguela Current System. Images courtesy of the NASA SeaWiFS project, representing the global biosphere from September 1997 to August 1998. 
the general pattern of coastal temperate seas, with diatom dominance in spring, a progressive contribution of heterotrophic organisms during summer, and a major contribution of dinoflagellates in late summer and early fall (Figure 7). However, this seasonal pattern shows considerable temporal and spatial heterogeneity, related to episodic wind-forcing cycles and different hydrographic structures. Observed patterns are a complex interplay of seasonal patterns influenced and modified by current and countercurrent systems and associated fronts, with upwelling favorable conditions versus relaxation of upwelling or downwelling that favor different algal species and assemblages. These successional patterns are instrumental in determining the temporal and spatial distribution of HABs.

Phytoplankton assemblage composition follows a mixing-stratification gradient and often presents a band-like distribution around an upwelling centre, corresponding to physico-chemical conditions (Figure 7). In a typical strong upwelling situation there may be a phytoplankton-poor inshore region (Type 1 water), followed in an offshore direction by a band of diatom dominance (Type 2 water) and by zones with an increasing contribution of other groups, such as dinoflagellates (Type 3 water), which are better adapted to stratified conditions (Margalef, 1978). This assemblage struc-

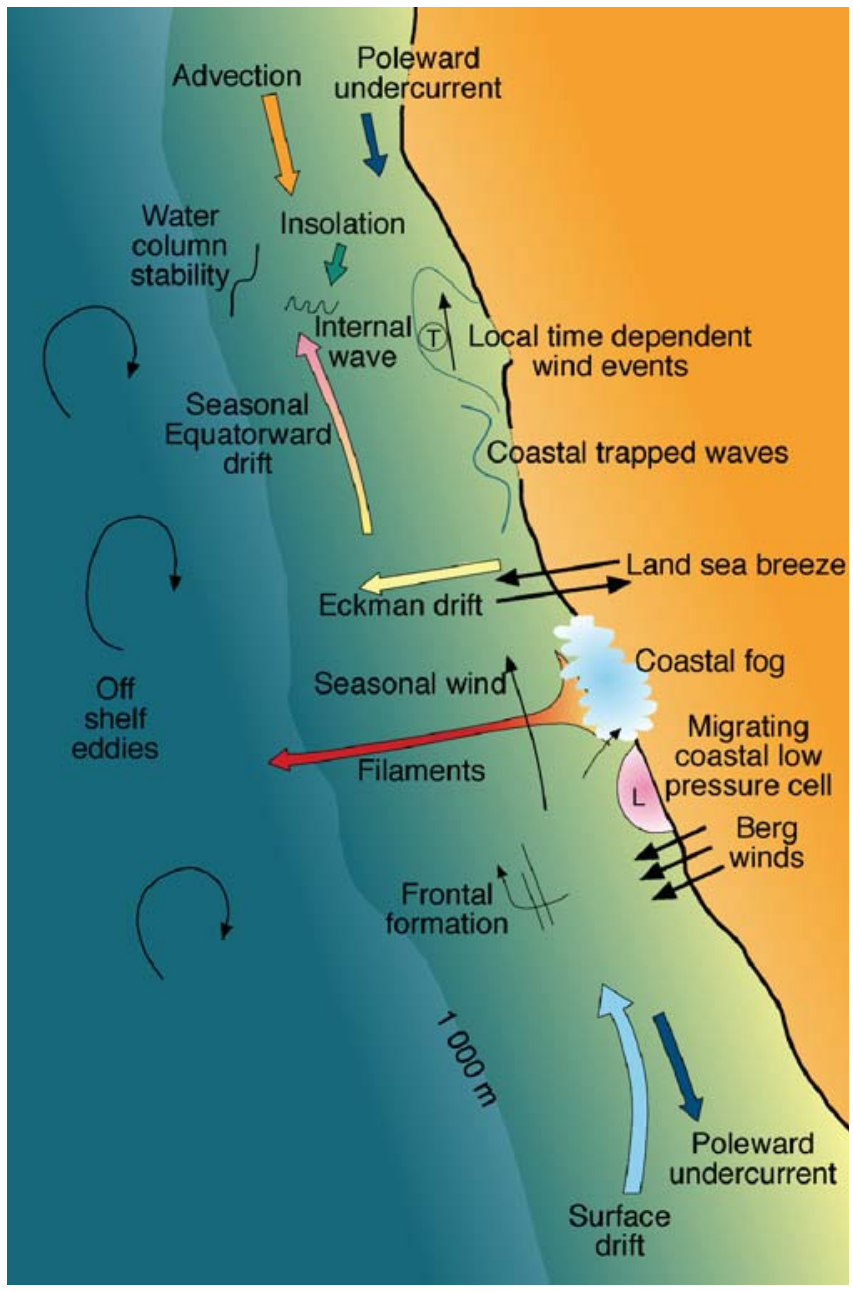

Figure 5. Schematic representation of the complex array of physical influences in the Benguela Current system. Wind is a dominant factor at all spatial scales, having a direct influence on large-scale currents, local upwelling and frontal dynamics, and the dynamics of the surface mixed layer. Consequently, $\mathrm{HABs}$ are closely linked to the prevailing winds of the Benguela Current system (from Shannon and Nelson, 1996). 
ture and species distribution will expand and contract in response to pulses of upwelling and relaxation. Consequently, phytoplankton succession in upwelling systems can be partially re-set in a fairly unique way. The physical forcing of upwelling leads to intermittent interruptions of succession, returning to earlier stages. The phase to which the succession is re-set will depend on the combination of wind-forcing intensity, degree of water column stratification, and the previous phase of succession (Estrada and Blasco, 1979). Latitudinal variation is largely driven by seasonal variability in temperature and stratification, but may also result from salinity stratification related to differences in continental runoff.

Chain-forming diatoms of medium and large size, such as Chaetoceros spp., Pseudo-nitzschia spp., and Thalassiosira spp. dominate spring and summer upwelling events in coastal waters. The offshore extent of the assemblage depends on the intensity of upwelling. As stratification strengthens and persists, dinoflagellate blooms may follow, and typically precede small-sized flagellate blooms after nutrients become limited. Large blooms of coccolithophorids may characterise these late stages of succession. Blooms of efficient swimmers, several of them chain-forming dinoflagellates such as Gymnodinium catenatum and Alexandrium spp., characterize the autumn upwelling-downwelling transition when
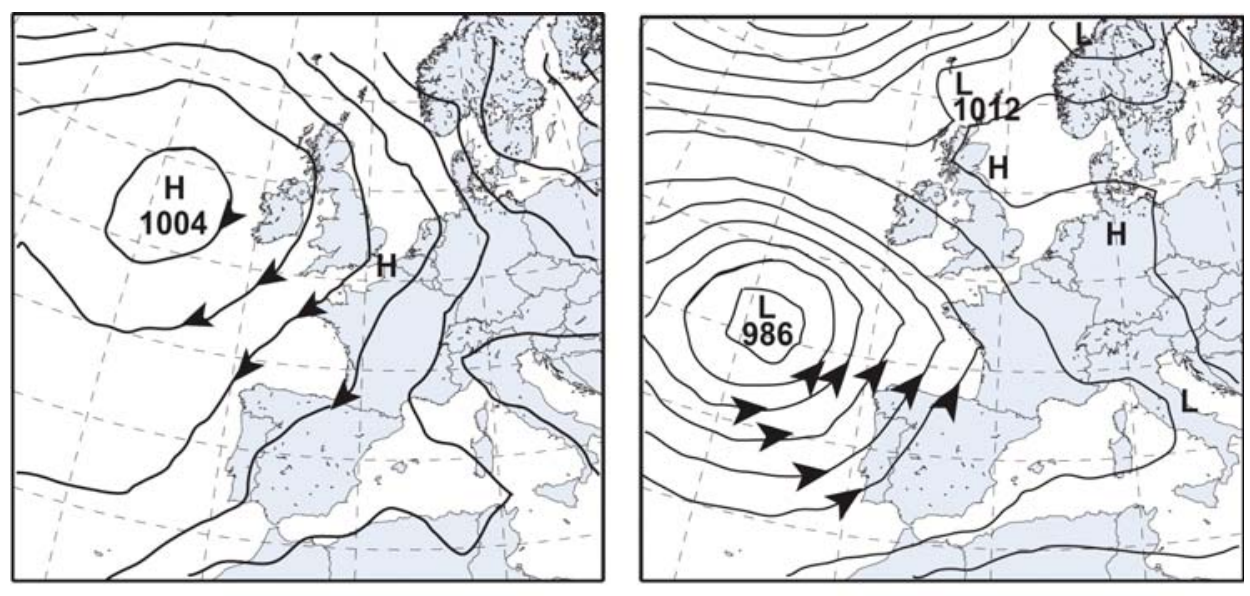

Figure 6. Typical meteorological and oceanographic situations found along the northwestern Iberian margin during summer and winter. Northerly winds cause upwelling and filament development in summer. During winter, southwesterly winds reinforce the surface poleward current. This results in characteristically cold, nutrient-rich upwelled waters near the coast in summer, replaced by warm, nutrient-depleted waters in winter. AVHRR images courtesy of the Remote Sensing Data Analysis Service, Plymouth Marine Laboratory, Plymouth, UK.
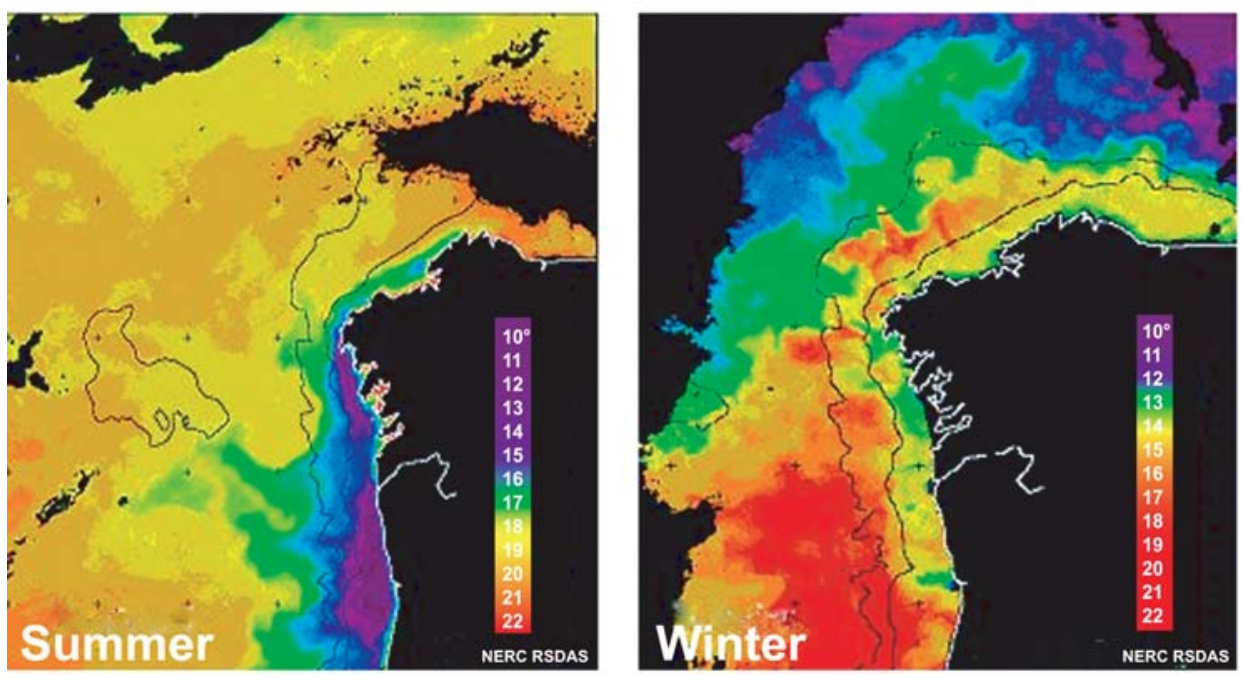
they concentrate in zones of convergence, while seasonal blooms of non-chain forming dinoflagellates such as Ceratium and Dinophysis are also prevalent. Outside the areas of upwelling, in stratified and oligotrophic (nutrient-poor) oceanic waters, phytoplankton assemblages are dominated by pico- and nanoplanktonic forms. Winter is also characterized by a relative depletion of the large chainforming diatoms, and an increase in abundance of more oceanic organisms. Superimposed on the seasonal succession of phytoplankton is smaller-scale spatial and temporal dynamics related primarily to the timing and intensity of wind forc- ing and reversal, and the development of spatial gradients in stratification. Therefore, although the phytoplankton community remains unpredictable at the species level, it shows systematic temporal and spatial trends in the dominance patterns of higher taxonomic levels linked to gradients of stratification.

\section{HARMFUL ALGAL BLOOMS}

Within the larger context of seasonal plankton succession, several potentially harmful microalgae are common to eastern boundary currents (Figure 8). Although upwelling systems are inherently advective, these $\mathrm{HAB}$ species have major

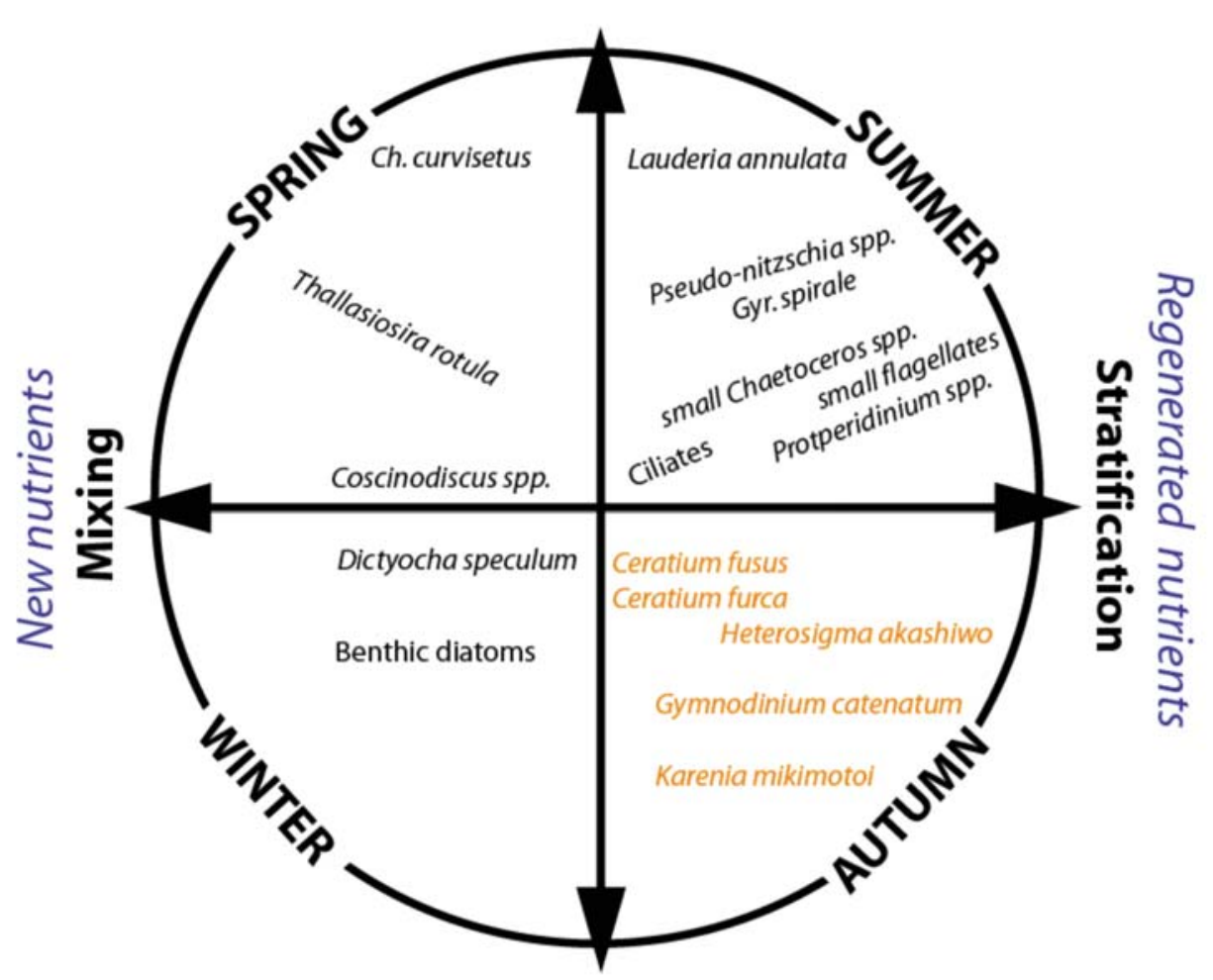

Figure 7. Annual cycle of phytoplankton abundance offshore Rias Baixas, Galicia according to a mixing-stratification (new versus regenerated nutrients) gradient (redrawn from Figueiras and Ríos, 1993 and Figueiras et al., 2002). impacts on both human activities and food web structure in these systems.

Two major toxin syndromes caused by HABs are found within the California Current System (CCS). These are paralytic shellfish poisoning (PSP) caused by members of the dinoflagellate genus Alexandrium and amnesic shellfish poisoning (DSP) caused by members of the diatom genus Pseudo-nitzschia (Horner et al., 1997). A third toxin syndrome, yessotoxin poisoning, may be present and associated with the dinoflagellates Protoceratium reticulatum in the north and Lingulodinium polyedrum in the south, but has not been extensively studied.

The CCS also has members of the dinoflagellate genera Dinophysis, responsible for diarrhetic shellfish poisoning (DSP) and Prorocentrum lima, responsible for okadaic acid poisoning, but these latter toxin syndromes are less-frequently observed and poorly understood compared to PSP and DAP. Other problem species include the diatom genus Chaetoceros, which kill fish primarily at aquaculture sites, but are not known to be harmful to humans; the dinoflagellates Noctiluca scintillans and Ceratium species and the ciliated protozoan Mesodinium rubrum, which cause obvious water discolorations; and the raphidophyte Heterosigma akashiwo, which is associated with fish kills and may be spreading (Horner et al., 1997).

The Iberian System has similar HAB problems. Of all the Iberian Pseudonitzschia species that have been isolated, cultured, and tested for the presence of toxicity, only $P$. australis is known to produce domoic acid. However, several species present in the region, for example, $P$. multiseries, $P$. subpacifica, and $P$. cf. pseu- 
dodelicatissima remain to be cultured and tested. In contrast, the CCS has multiple toxin-producing Pseudo-nitzschia species, including P. australis, $P$. fraudulenta, P. heimii, P. multiseries, P. pungens, P. delicatissima, and P. cf. pseudodelicatissima (Fryxell et al., 1997) (Figure 9).

In the Iberian system, Dinophysis species have the greatest economic impact on shellfish harvests owing to their persistence for much of the year albeit in moderate numbers $\left(10^{2}\right.$ to $10^{3}$ cells $\left./ \mathrm{L}\right)$. D. acuminata and D. acuta often coexist but maximum concentrations do not coincide in space or in time. D. acuminata maxima are typically found in the north and associated with lower temperatures and salinities, whereas D. acuta concentrations are typically higher in the south. Despite their preference for stratified waters, these species bloom inshore of the upwelling front during summer and may at times be the only dinoflagellate representatives within chain-forming diatom assemblages. The presence of increased numbers of Dinophysis species and DSP outbreaks has been associated with two different scenarios: in situ growth favored by periods of stratification between moderate pulses of upwelling, and downwelling events that promote the accumulation of Dinophysis (Reguera et al., 2003; Sordo et al., 2001).

Between 1985 and 1995, major toxic events on the Iberian coast were ascribed to blooms of the chain-forming dinoflagellate and cyst producer G. catenatum, a species that is responsible for PSP and seems to have spread along the Iberian coast over the years. However, the most recent blooms have been restricted to the Alboran Sea eddy in the Mediterranean Sea. In recent years, L. polyedrum
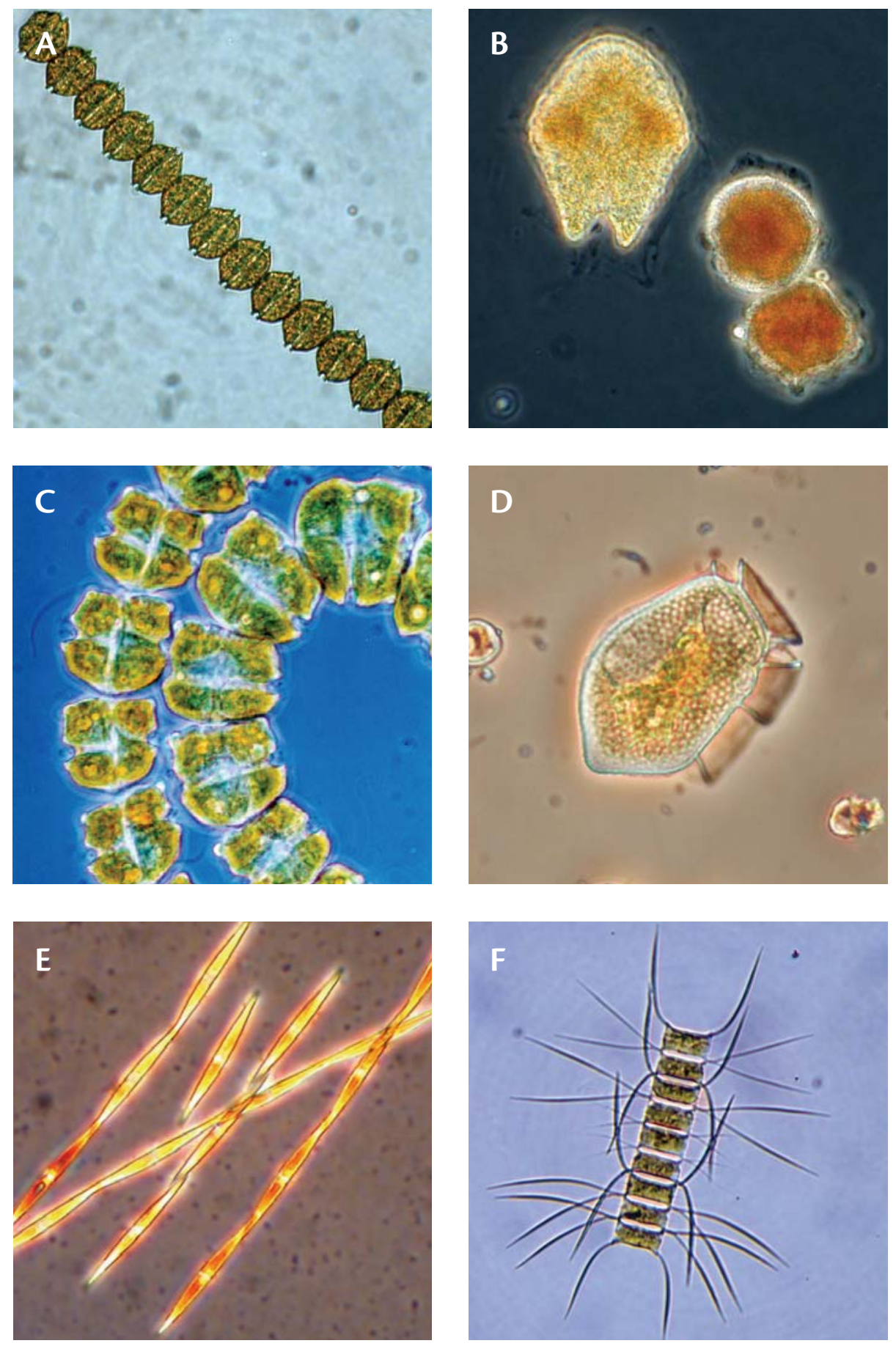

Figure 8. Photomicrographs of HAB organisms commonly found in upwelling regimes worldwide: (A) chain of Alexandrium catenella, which causes paralytic shellfish poisoning (PSP); (B) red tide causing dinoflagellate Akashiwo sanguinea (large cell) accompanied by two Lingulodinium polyedrum cells, which cause yessotoxin poisoning; (C) chain of Gymnodinium catenatum, which causes PSP; (D) Dinophysis acuta, which causes diarrhetic shellfish poisoning (DSP); (E) Pseudo-nitzschia australis, which causes amnesic shellfish poisoning (ASP); (F) chain of Chaetoceros sp., responsible for fish kills. Images courtesy NOAA Fisheries, Seattle, WA (A,E,F), the Center for Integrated Marine Technology (B), T. Moita (C), and F. Figueiras (D). 
has bloomed in the southern Iberian

Atlantic area, in warm stratified waters compressed by adjacent upwelling, and offshore northern Rías, Galicia, where major blooms were recorded in 2003 (Amorim et al., in press). Karenia mikimotoi (responsible for fish kills) is also frequently found in late summer-early autumn within the Iberian System.

HABs in the Benguela Current are also typically attributed to one or another toxic or high-biomass dinoflagellate species (Figure 3). Harmful impacts attributed to high-biomass blooms, which ultimately lead to low-oxygen events and in some cases the production of hydrogen sulfide, have for many years led to spectacular mortalities of marine organisms in the Benguela Current. The northern Benguela Current system is characterized by the fish-killing dinoflagellate Karlodinium micrum (previously known as Gymnodinium galatheanum). The distribution of this species does not, however, appear to extend into the southern Benguela Current. Another fish-killing dinoflagellate is the newly from New Zealand waters, Karenia brevisulcata, in that it also produces an aerosol toxin responsible for respiratory and skin disorders.
Pseudo-nitzschia australis has been identified as a very common bloomforming organism in all three systems, but, in marked contrast to the CCS

\section{HABs in upwelling systems have been closely linked to wind, which is the main driving force in upwelling systems...}

As in the CCS, blooms of Alexandrium catenella, responsible for PSP, are common in the southern Benguela Current and have historically been the primary concern of marine scientists and managers. A. catenella in the Benguela Current can be found at exceedingly high cell concentrations of many million cells/L and these blooms not only render shellfish toxic to consumers, but are also seemingly responsible for fish and shellfish mortalities (Pitcher and Calder, 2000). The other very common form of shellfish poisoning in the Benguela Cur-

\section{...upwelling circulation overrides both the}

\section{nutrient limitation of stratified waters and the light limitation of well-mixed waters...}

described species Karenia cristata (Botes et al., 2003). Initially responsible for large abalone mortalities in the 1980s, this species appears to be restricted to the southern Benguela Current. It shares several characteristics with Karenia bre$v i s$ and the recently described species rent, as in the Iberian system, is DSP, usually attributable to Dinophysis acuminata or Dinophysis fortii. Dinophysis species often form relatively minor components of blooms dominated by other dinoflagellates, but can nevertheless also attain high cell concentrations. and Iberian system, to date no trace of domoic acid has been found in cultures and no form of shellfish poisoning has been associated with these blooms in the Benguela Current (Marangoni et al., 2001). Similarly, Protoceratium reticulatum and Lingulodinium polyedrum are known to bloom in the southern Benguela Current, but no attempts have been made to establish the presence of yessotoxins.

\section{KEY QUESTIONS}

Based on the current knowledge and understanding of HABs in these three upwelling systems, eight key questions were developed as part of the GEOHAB Open Science Meeting on HABs in Upwelling Systems (GEOHAB, 2005). These questions are intended to provide research foci for regional and international research collaboration and are briefly described.

A. Are there definable adaptive strategies that characterize HAB species in upwelling systems? Upwelling habitats are mosaics of multiple and shifting subhabitats, whose physical and chemical properties exhibit sharp spatial and temporal heterogeneities, a variability that 
leads to many niche types and disruptions. A major unresolved issue is whether there are adaptive features characteristic of the species common to upwelling systems and how these adaptations differ from species in non-upwelling systems.

B. What seeding strategies persist within upwelling regions and are they consistent among regions? Upwelling systems are inherently advective, and, as such, provide a unique selective pressure on phytoplankton population maintenance. To counter advective washout, phytoplankton may require species-specific seeding strategies to facilitate bloom initiation and persistence. Because the seeding strategies for HAB organisms are poorly understood and the sites of seed beds are not well described for upwelling systems, little is known about the interand intraspecific differences in seeding strategies among upwelling regions, or the role of seeding in the maintenance of HAB populations.

C. How do small-scale physical processes affect $\mathrm{HAB}$ growth and dispersion in upwelling systems? The surface boundary layer is the conduit between atmospheric forcing (wind stress and surface heat flux) and the oceanic response, incorporating the response of the phytoplankton community to changes in the upper-water-column structure. Turbulent mixing also selects for discrete species or subpopulations capable of handling the competing influences of shear and nutrient availability. Addressing the varying responses in terms of the succession of species within and among upwelling systems will allow inferences of the properties of the upper water column, which are important in regulating species succession and the development of HABs.
Juan de Fuca Eddy

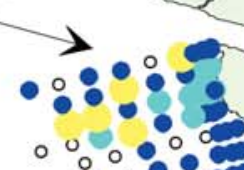

$\circ 0$ 5830

WA

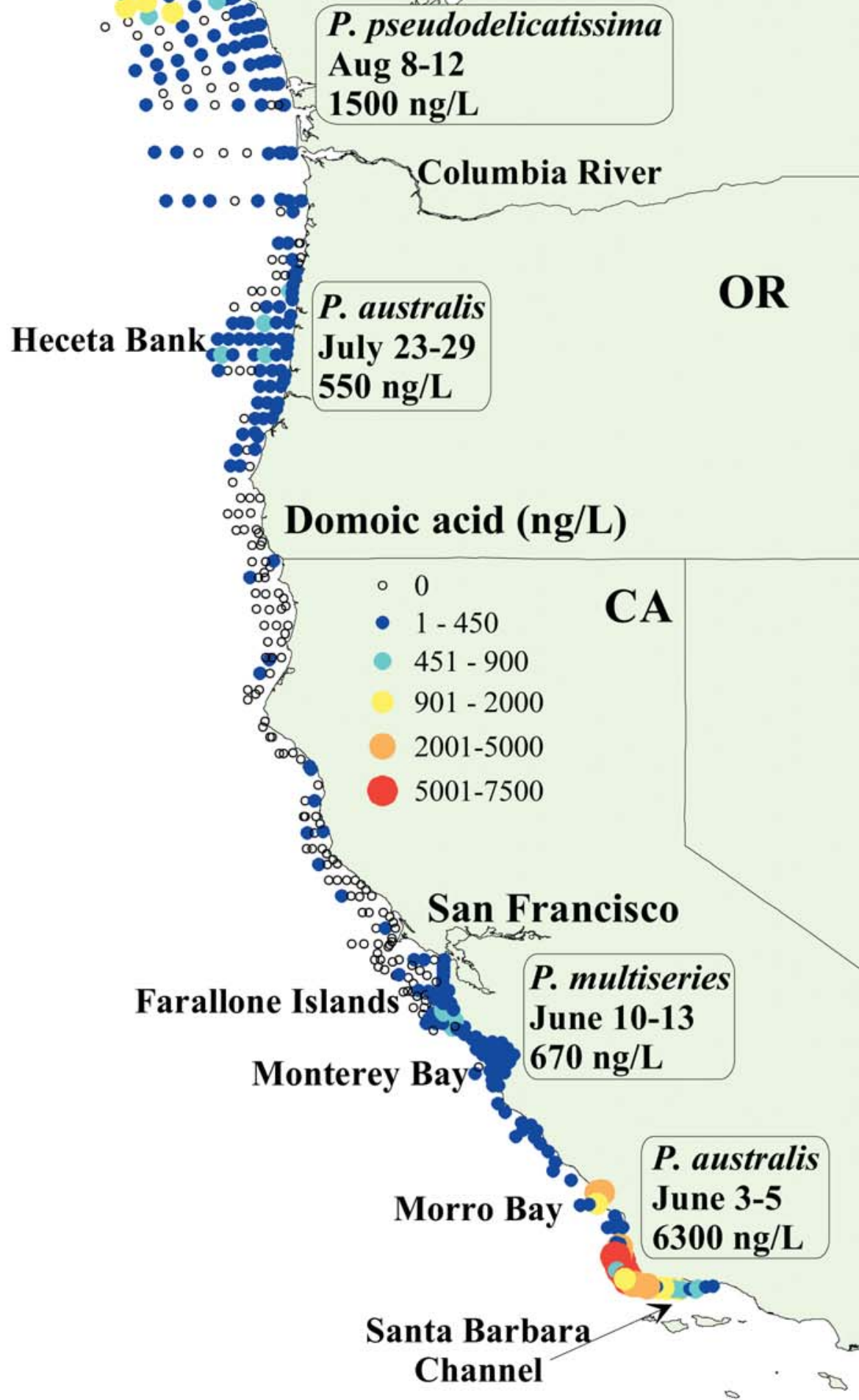

Figure 9. Dominance of different toxin-producing Pseudo-nitzschia species in the California Current System during a coast-wide HAB event that occurred in summer 1998, which resulted in massive marine mammal and sea bird mortalities. Circles represent sample locations, while colors represent domoic acid concentration, ranging from undetectable (open circle) to greater than $5000 \mathrm{ng} / \mathrm{L}$ (red). During this period, at least three toxin-producing species were present in four distinct geographical regions (from Trainer et al., 2000). 
D. How do nutrient supply type and ratios determine $\mathrm{HAB}$ population $d y$ namics in upwelling systems? Coastal upwelling ecosystems represent the extreme case of natural new nutrient input and thus are characterized by intense blooms of both harmful and benign species. Given the variable association of HABs with different phases of the upwelling cycle and potentially, terrestrial input, different the ecological factors that contribute to cellular toxicity.

\section{F. How does coastal morphology and} bathymetry affect $\mathrm{HAB}$ dynamics in upwelling systems? The dynamics of coastal upwelling systems are affected to a large extent by the continental shelf and upper slope bathymetry, and by coastline morphology. These influences are responsible for generating alternating patterns of

\section{Unlike many other ecosystems impacted by}

\section{harmful algae, upwelling systems worldwide}

are dominated by a common set of physical

parameters and are likely to respond similarly, regardless of locale.

HAB life-forms are likely characterized by distinct nutrient acquisition strategies.

$\mathrm{E}$. What is the role of genetic predisposition versus environmental conditions in toxin production in different upwelling systems within a given genus or species? Variability in toxin production is likely caused by a combination of genotype and environmental conditions and elucidation of these respective roles in toxigenicity is critical in developing a predictive capability. Pseudo-nitzschia australis, for example, is typically toxic and blooms in large numbers in the California system. It is found at lower concentrations and toxicity in the Iberian system, and is often abundant but apparently never toxic in the Benguela Current system. Comparative studies of these harmful taxa and the ecosystems in which they occur can assist in differentiating between genetic predisposition and active and passive upwelling circulations along the coast that may serve in creating sites favouring HAB initiation, retention or dispersion.

G. What is the relative importance of cross-shelf and along-shore advection in different upwelling systems for HABs? Differences in the wind regime and the presence of specific topographic features also induce modifications in along-shore and cross-shelf flows at several temporal and spatial scales characteristic for each upwelling system, as well as changes in along-shore versus cross-shelf transport. Cross-shelf transport can be relatively more significant in areas with embayments and promontories, where accumulation and dispersion of HABs may be favored, while along-shore transport may be more important in places with straight coastlines.

$\mathrm{H}$. Are climate indicators predictive of HAB events in upwelling systems? Earth's climate has warmed by approximately 0.6 degrees $\mathrm{C}$ over the past 100 years, showing an acceleration in warming since the mid-1970s (Walther et al., 2002). Significant evidence exists to demonstrate that variations in upwelling intensities and locations have occurred in concert with this warming trend. HABs are local phenomena, and as with other organisms, populations or ecological communities are likely to respond to regional changes more than approximated global averages. Comparisons among regions will provide insight into the separation of local versus basin or climatic scales.

\section{NEXT STEPS}

Our understanding of and ability to predict HABs in upwelling systems over the next 5 to 10 years will reflect the extent to which we have addressed these key questions. How do we as a community accomplish this? We believe that a comprehensive understanding of the population dynamics of HABs requires the integration of oceanographic studies with the application of models to comparable ecosystem types. We invite the HAB and oceanographic community to review the GEOHAB literature (GEOHAB, 2001, 2003, 2005), and begin to frame future research objectives and plans to address these goals.

\section{ACKNOWLEDGEMENTS}

We thank the participants of the Open Science Meeting on Harmful Algal Blooms in Upwelling Systems, held 17-20 November 2003, for their knowledge and ideas that contributed to this summary paper. GEOHAB is an initia- 
tive of SCOR (Scientific Committee on Oceanic Research) and IOC (Intergovernmental Oceanographic Commission of UNESCO). R. Kudela was funded by NOAA ECOHAB and the National Science Foundation. 四

\section{REFERENCES}

Alvarez-Salgado, X.A., F.G. Figueiras, F.F. Pérez, S. Groom, E. Nogueira, A. Borges, L. Chou, C.G. Castro, G. Moncoiffe, A.F. Ríos, A.E.J. Miller, M. Frankignoulle, G. Savidge and R. Wollast. 2003. The Portugal Coastal Counter Current off NW Spain: New insights on its biogeochemical variability. Progress in Oceanography 56:281-321.

Amorim, A.J., M.T. Moita, and P. Oliveira. In press. Dinoflagellate blooms related to coastal upwelling plumes off Portugal. Proceedings of the $10^{\text {th }}$ International Conference on Harmful Algal Blooms, K. Steidinger et al., eds. Intergovernmental Oceanographic Commission of UNESCO, Paris, France.

Barlow, R.G. 1982. Phytoplankton ecology in the southern Benguela current. 1. Biochemical composition. Journal of Experimental Marine Biology and Ecology 63:239-248.

Botes, L., S.D. Sym, and G.C. Pitcher. 2003. Karenia cristata sp. Nov. and Karenia bicuneiformis sp. Nov. (Gymnodiniales, Dinophyceae): Two new Karenia species from the South African coast. Phycologia 42:563-571.

Chavez, F.P., J. Ryan, S.E. Lluch-Cota, and C.M. Niquen. 2003. From anchovies to sardines and back: Multidecadal change in the Pacific Ocean. Science 299:217-221.

Estrada, M. and D. Blasco. 1979. Two phases of the phytoplankton community in the Baja California upwelling. Limnology and Oceanography 24:1065-1080.

Figueiras, F.G. and A.F. Rios. 1993. Phytoplankton succession, red tides, and the hydrographic regime in the Rías Bajas of Galicia. Pp. 239-244 in Toxic Phytoplankton Blooms in the Sea, T. J. Smayda and Y. Shimizu, eds. Elsevier Science Publishers B.V. New York, NY.

Figueiras, F.G., U. Labarta. and M. J. Fernández Reiriz. 2002. Coastal upwelling, primary production and mussel growth in the Rías Baixas of Galicia. Hydrobiologia 484:121-131.

Fryxell, G.A., M.C. Villac, and L.P. Shapiro. 1997. The occurrence of the toxic diatom genus
Pseudo-nitzschia (Bacillariophyceae) on the west coast of the USA, 1920-1996: A review. Phycologia 36:419-437.

GEOHAB. 2001. Global Ecology and Oceanography of Harmful Algal Blooms, Science Plan. P. Glibert and G. Pitcher, eds. SCOR and IOC, Baltimore and Paris, 86 pp.

GEOHAB. 2003. Global Ecology and Oceanography of Harmful Algal Blooms, Implementation Plan. P. Gentien, G. Pitcher, A. Cembella and P. Glibert, eds. SCOR and IOC, Baltimore and Paris, $36 \mathrm{pp}$.

GEOHAB. 2005. Global Ecology and Oceanography of Harmful Algal Blooms, GEOHAB Core Research Project: HABs in Upwelling Systems, G. Pitcher, T. Moita, V. Trainer, R. Kudela, P. Figueiras, T. Probyn, eds. SCOR and IOC, Paris and Baltimore, 82 pp.

Hickey, B.M. 1998. Coastal oceanography of western North America from the tip of Baja California to Vancouver Island. Pp. 345-393 in The Sea, Volume 11, K.H Brink and A.R. Robinson, eds. John Wiley and Sons, Inc., New York.

Hood, R.R., S. Neuer, and T.J. Cowles. 1992. Autotrophic production, biomass and species composition at two stations across an upwelling front. Marine Ecology Progress Series 83:221-232.

Horner, R.A., D.L. Garrison, and F.G. Plumley. 1997. Harmful algal blooms and red tide problems on the U.S. west coast. Limnology and Oceanography 42(5, Part 2):1076-1088.

Marangoni, C., R.N. Pienaar, S.D. Sym, and G.C. Pitcher. 2001. Pseudo-nitzschia australis Frenguelli from Lambert's Bay South Africa. Proceedings of the Microscopy Society of South Africa 31:53.

Margalef, R. 1978. Phytoplankton communities in upwelling areas. The example of NW Africa. Oecologia Aquatica 3:97-132.

Pitcher, G.C., and D. Calder. 2000. Harmful algal blooms of the southern Benguela current: A review and appraisal of monitoring from 1989 to 1997. South African Journal of Marine Science 22:255-271.

Pitcher, G.C., A.J. Boyd, D.A. Horstman, and B.A. Mitchell-Innes. 1998. Subsurface dinoflagellate populations, frontal blooms and the formation of red tide in the southern Benguela upwelling system. Marine Ecology Progress Series 172:243-264.

Reguera, B., E. Garcés, I. Bravo, Y. Pazos, and I. Ramilo. 2003. In situ division rates of several species of Dinophysis estimated by a post- mitotic index. Marine Ecology Progress Series 249:117-131.

Shannon, L.V., and G. Nelson. 1996. The Benguela: Large scale features and processes and system variability. Pp. 163-210 in The South Atlantic: Past and Present Circulation, G. Wefer, W.H. Berger, G. Siedler and D.J. Webb, eds. Springer-Verlag, Berlin, Germany.

Shannon, L.V., A.J. Boyd, G.B. Brundrit, and J. Taunton-Clark. 1986. On the existence of an El Niño-type phenomenon in the Benguela system. Journal of Marine Research 44:495520.

Sherman, K., and L.M. Alexander, eds. 1986. Variability and management of large marine ecosystems. AAAS Selected Symposium 99. Westview Press, Boulder, CO, 319 pp.

Smith, R.L. 1992. The physical processes of coastal ocean upwelling systems. Pp. 39-64 in Upwelling in the Ocean: Modern Processes and Ancient Records, C.P. Summerhayes, K.-C. Emeis, M.V. Angel, R.L. Smith and B. Zeitzschel, eds. John Wiley and Sons Ltd., Chichester, UK.

Sordo, I., E.D. Barton, J.M. Cotos, and Y. Pazos. 2001. An inshore poleward current in the NW of the Iberian Peninsula detected from satellite images, and its relation with G. catenatum and D. acuminata blooms in the Galician rias. Estuarine and Coastal Shelf Science 53:787-799.

Trainer, V.L., N.G. Adams, B.D. Bill, C.M. Stehr, J.C. Wekell, P. Moeller, M. Busman, and D. Woodruff. 2000. Domoic acid production near California upwelling zones, June 1998. Limnology and Oceanography 45(8):401-440. Walther, G.R., E. Post, P. Convey, A. Menzel, C. Parmesani, T.J.C. Beebee, J-M. Fromentin, O. Hoeg-Guldberg, and F. Bairlein. 2002. Ecological response to recent climate change. Nature 416:389-395.

Oceanography | Vol.18, No.2, June 2005 